\title{
Production of Antibodies for Selective Detection of Malachite Green and the Related Triphenylmethane Dyes in Fish and Fishpond Water
}

\author{
MeI-Chun Yang ${ }^{\dagger}$ Jim-Min FAng, ${ }^{*}, *$ TzOng-Fu Kuo,${ }^{\S}$ DA-Ming Wang, ${ }^{*}$ \\ Yi-Lin Huang, ${ }^{\ddagger}$ Liang-YiRn LiU, ${ }^{\dagger}$ Pen-Heng Chen, ${ }^{\dagger}$ AND \\ TONG-HSUAN $\mathrm{CHANG}^{\dagger}$
}

GlycoNex Inc., Taipei County, 221, Taiwan, Department of Chemistry, National Taiwan University, Taipei, 106, Taiwan, and Department of Veterinary Medicine, National Taiwan University, Taipei, 106, Taiwan

\begin{abstract}
This study provides a practical method for production of the antibodies against malachite green (MG) and its primary metabolite leucomalachite green (LMG). Two ELISA kits are constructed with the MG and LMG antibodies for detection of the residual MG and LMG in fish muscle and fishpond water. The detection limit is established at the level of $0.05 \mu \mathrm{g} / \mathrm{L}$ for both $\mathrm{MG}$ and LMG. Our ELISA kits show the advantages of good specificity, high sensitivity, and convenience in rapid screening of MG and LMG residues. The sample of fishpond water, without extraction or prior preparation, is directly assayed by the ELISA kit. More then 80 fish samples can be simultaneously tested in a kit. The toxic crystal violet and its metabolite leucocrystal violet of illegal use in aquaculture are detected by our prepared MG and LMG antibodies, whereas the antibodies do not cross-react with common antibiotics, sulfonamides, and benzene derivatives.
\end{abstract}

KEYWORDS: Malachite green; leucomalachite green; antibody; ELISA; fish

\section{INTRODUCTION}

Malachite green (MG, see Figure 1) (1), a dye of triphenylmethane skeleton, has been extensively used in aquaculture for prevention and treatment of external fungal and parasitic infections in fish. MG is easily absorbed by fish during waterborne exposure and is rapidly metabolized into leucomalachite green (LMG, see Figure 1). The reduction derivative LMG is recognized as a major metabolite of $\mathrm{MG}$ in fish $(2,3)$ and will store in fish muscle and tissues for months. Like other triphenylmethane dyes, MG and LMG cause carcinogenesis, mutagenesis, chromosomal fractures, teratogenesis, and respiratory toxicity in animals (4-7). Use of MG in aquatic food animals is highly restricted or banned in several countries because of toxicological considerations. However, illegal use of MG continues worldwide in aquaculture due to its low cost and ready availability $(8,9)$.

Surveillance of MG and LMG in aquaculture products is a necessary means to protect human health. According to the European Commission and U.S. Food \& Drug Administration (10), methods that can be used for the determination of MG residues in fish muscles should meet a minimum required

* To whom correspondence should be addressed. Tel: (8862)3366 1663. Fax: (8862)2363 7812 . E-mail: jmfang@ntu.edu.tw.

GlycoNex Inc.

* Department of Chemistry, National Taiwan University.

${ }^{\S}$ Department of Veterinary Medicine, National Taiwan University. performance limit of $2 \mu \mathrm{g} / \mathrm{kg}$ for the sum of MG and LMG. High-performance liquid chromatography (HPLC) and liquid chromatography-mass spectrometry (LC-MS) are two general techniques for the quantitative analysis of MG and LMG in fish tissues (11-29). These techniques rely on expensive instruments operated by well-trained analysts, and prior preparation of samples is time-consuming and is not ideal for screening large number of samples. Alternatively, enzyme-linked immunosorbent assay (ELISA) is a rapid, specific, and sensitive method that is applicable to the on-site examination of a large number of samples. We thus generated two types of polyclonal antibodies against MG and LMG, and further developed the indirect competitive ELISA.

\section{MATERIALS AND METHODS}

All solvents and reagents were reagent-grade and were used without further purification. Crystal violet (CV, see Figure 1) chloride and malachite green oxalate were purchased from Merck (Rahway, NJ). Leucomalachite green, leucocrystal violet, Freund's complete/incomplete adjuvant, bovine serum albumin (BSA), ovalbumin (OVA), and goat anti-rabbit IgG-HRP were purchased from Sigma-Aldrich (St. Louis, MO).

Melting points are uncorrected. Infrared (IR) spectra were recorded on a Nicolet Magna 550-II spectrometer. Proton NMR $\left({ }^{1} \mathrm{H}\right.$ NMR $)$ and carbon NMR $\left({ }^{13} \mathrm{C}\right.$ NMR and DEPT) spectra were recorded on Varian Unity Plus-400 (400 MHz) and Bruker Avance-400 FT-NMR spectrometers; chemical shifts are reported in unit $\delta$ relative to tetramethylsilane (TMS) with residual protons in the solvent as an internal 


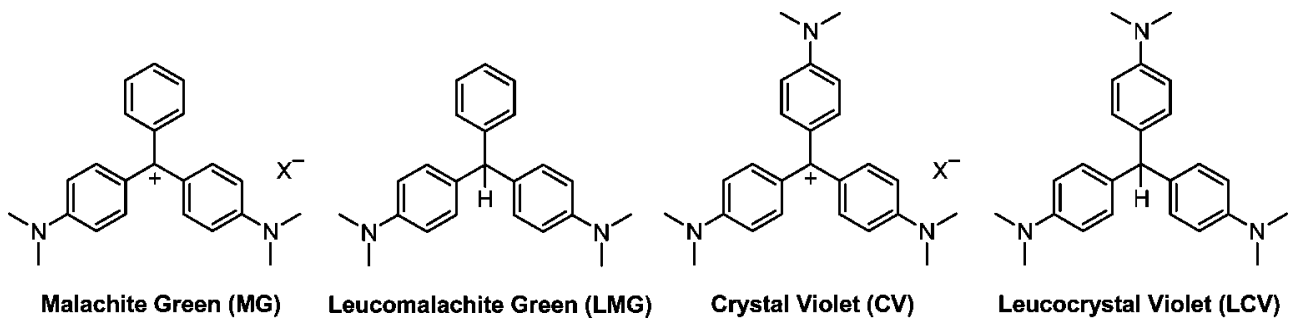

Figure 1. Structures of MG, LMG, CV, and LCV.

standard: $\mathrm{CDCl}_{3}, \delta 7.24$ (for ${ }^{1} \mathrm{H}$ NMR) and $\delta 77.0$ (for ${ }^{13} \mathrm{C} \mathrm{NMR}$ and DEPT). Mass spectra (MS) and high-resolution mass spectra (HRMS) were measured using a JEOL JMS-HX 110 spectrometer. Optical density (OD) of ELISA was measured using an ELISA reader (THERMOmax, Molecular Device, USA).

All experiments requiring anhydrous conditions were performed under an atmosphere of nitrogen. Reactions were monitored by thinlayer chromatography (TLC) using slides precoated with a $0.25 \mathrm{~mm}$ layer of silica gel containing a fluorescent indicator. Column chromatography was carried out on Kieselgel $60(40-63 \mu \mathrm{m})$.

Synthesis of Carboxyleucomalachite Green (CLMG, 3). Method $A$. According to the previously described procedure (30), a mixture of 4-formylbenzoic acid (900 mg, $6 \mathrm{mmol}$ ), freshly distilled $\mathrm{N}, \mathrm{N}$ dimethylaniline $(2.4 \mathrm{~mL}, 19 \mathrm{mmol})$, and anhydrous $\mathrm{ZnCl}_{2}(2.4 \mathrm{~g}, 18$ $\mathrm{mmol})$ in absolute ethanol $(60 \mathrm{~mL})$ was heated at reflux for $24 \mathrm{~h}$ under an atmosphere of nitrogen. The mixture was cooled, and methanol (30 $\mathrm{mL})$ and aqueous $\mathrm{HCl}(1 \mathrm{M})$ were added until $\mathrm{pH}=5$ to give slightly greenish crystals. The crystals were collected by filtration, rinsed with water, and dried over $\mathrm{KOH}$ in vacuum to give $1.8 \mathrm{~g}$ of 4-[bis(4dimethylaminophenyl)methyl] benzoic acid, CLMG (3) (30-34), in 80\% yield.

Method B. Under an atmosphere of nitrogen, a mixture of methyl 4-formylbenzoate $(0.55 \mathrm{~g}, 3.4 \mathrm{mmol}), \mathrm{N}, \mathrm{N}$-dimethylaniline $(1.5 \mathrm{~mL}$, $11.8 \mathrm{mmol})$ and conc $\mathrm{H}_{2} \mathrm{SO}_{4}(0.25 \mathrm{~mL}$ of $96 \%$ solution $)$ was heated at $120{ }^{\circ} \mathrm{C}$ for $40 \mathrm{~h}$. The mixture was cooled, diluted with $\mathrm{CH}_{2} \mathrm{Cl}_{2}(10$ $\mathrm{mL})$, and washed with water $(10 \mathrm{~mL})$. The organic phase was concentrated, and the residue was purified by flash chromatography on a silica gel column with elution of hexane/EtOAc (9:1) to afford CLMG methyl ester (1.14 g, 88\% yield). To a solution of CLMG methyl ester $(1.03 \mathrm{~g}, 2.65 \mathrm{mmol})$ in THF $(7 \mathrm{~mL})$ was added aqueous $\mathrm{NaOH}$ ( $3 \mathrm{~mL}$ of $1 \mathrm{M}$ solution). The mixture was heated at reflux for $20 \mathrm{~h}$, cooled, and extracted with EtOAc $(10 \mathrm{~mL} \times 3)$. The aqueous layer was acidified to $\mathrm{pH} 5$ with $\mathrm{HCl}$ solution $(3 \mathrm{M})$, and extracted with $\mathrm{CH}_{2} \mathrm{Cl}_{2}(50 \mathrm{~mL} \times 3)$. The $\mathrm{CH}_{2} \mathrm{Cl}_{2}$ layer was dried over anhydrous $\mathrm{Mg}_{2} \mathrm{SO}_{4}$, filtered, and concentrated under reduced pressure to give CLMG (806 mg, $81 \%$ yield).

CLMG. Light greenish solid, $\mathrm{mp}=250{ }^{\circ} \mathrm{C}$ (decomposed); IR (KBr) 3417, 2886, 1682, 1651, 1611, 1519, 1349, 1293, 1166 $\mathrm{cm}^{-1} ;{ }^{1} \mathrm{H}$ NMR $\left(\mathrm{CDCl}_{3}, 400 \mathrm{MHz}\right) \delta 7.98(2 \mathrm{H}, \mathrm{d}, J=8.4$ $\mathrm{Hz}), 7.22$ (2 H, d, $J=8.4 \mathrm{~Hz}), 6.95-6.93(4 \mathrm{H}, \mathrm{m}), 6.66(4 \mathrm{H}$, $\mathrm{d}, J=8.8 \mathrm{~Hz}), 5.42(1 \mathrm{H}, \mathrm{s}), 2.90(12 \mathrm{H}, \mathrm{s}) ;{ }^{13} \mathrm{C} \mathrm{NMR}\left(\mathrm{CDCl}_{3}\right.$, $100 \mathrm{MHz}) \delta 171.01,151.25(2 \times), 148.44(2 \times), 131.62,129.68$ $(2 \times), 129.51(4 \times), 129.05(2 \times), 126.61,112.54(4 \times), 55.23$, $41.08(2 \times)$; HRMS (ESI) calculated for $\mathrm{C}_{24} \mathrm{H}_{27} \mathrm{~N}_{2} \mathrm{O}_{2}$ : 375.2073, found: $m / z, 375.2022\left[\mathrm{M}^{+}+\mathrm{H}\right]$.

CLMG Methyl Ester. White solid, $\mathrm{mp}=128-129{ }^{\circ} \mathrm{C}$; TLC (EtOAc/hexane (1:9)) $R_{f}=0.10$; IR (KBr) 2800, 1720, 1612, $1519,1441,1343,1279,1110,1102 \mathrm{~cm}^{-1} ;{ }^{1} \mathrm{H}$ NMR $\left(\mathrm{CDCl}_{3}\right.$, $400 \mathrm{MHz}) \delta 7.90(2 \mathrm{H}, \mathrm{d}, J=8.4 \mathrm{~Hz}), 7.19(2 \mathrm{H}, \mathrm{d}, J=8.4$ $\mathrm{Hz}), 6.95-6.93$ (4 H, m), $6.64(4 \mathrm{H}, \mathrm{d}, J=8.8 \mathrm{~Hz}), 5.40(1 \mathrm{H}$, s), $3.87(3 \mathrm{H}, \mathrm{s}), 2.91(12 \mathrm{H}, \mathrm{s}) ;{ }^{13} \mathrm{C} \mathrm{NMR}\left(\mathrm{CDCl}_{3}, 100 \mathrm{MHz}\right)$ $\delta 166.45,150.35(2 \times), 148.37(2 \times), 131.50,129.46(4 \times)$, $129.01(2 \times), 128.92(2 \times), 127.28,112.27(4 \times), 55.11,52.11$, 40.95 (4×); HRMS (ESI) calculated for $\mathrm{C}_{25} \mathrm{H}_{29} \mathrm{~N}_{2} \mathrm{O}_{2}$ : 389.2229 , found: $m / z, 389.2259\left[\mathrm{M}^{+}+\mathrm{H}\right]$.

Synthesis of Carboxymalachite Green (CMG, 4). Method A. According to the previously described procedure (30-34), a mixture of CLMG (375 mg, $1 \mathrm{mmol}$ ), chloranil (295 mg, $1.2 \mathrm{mmol})$, and glacial
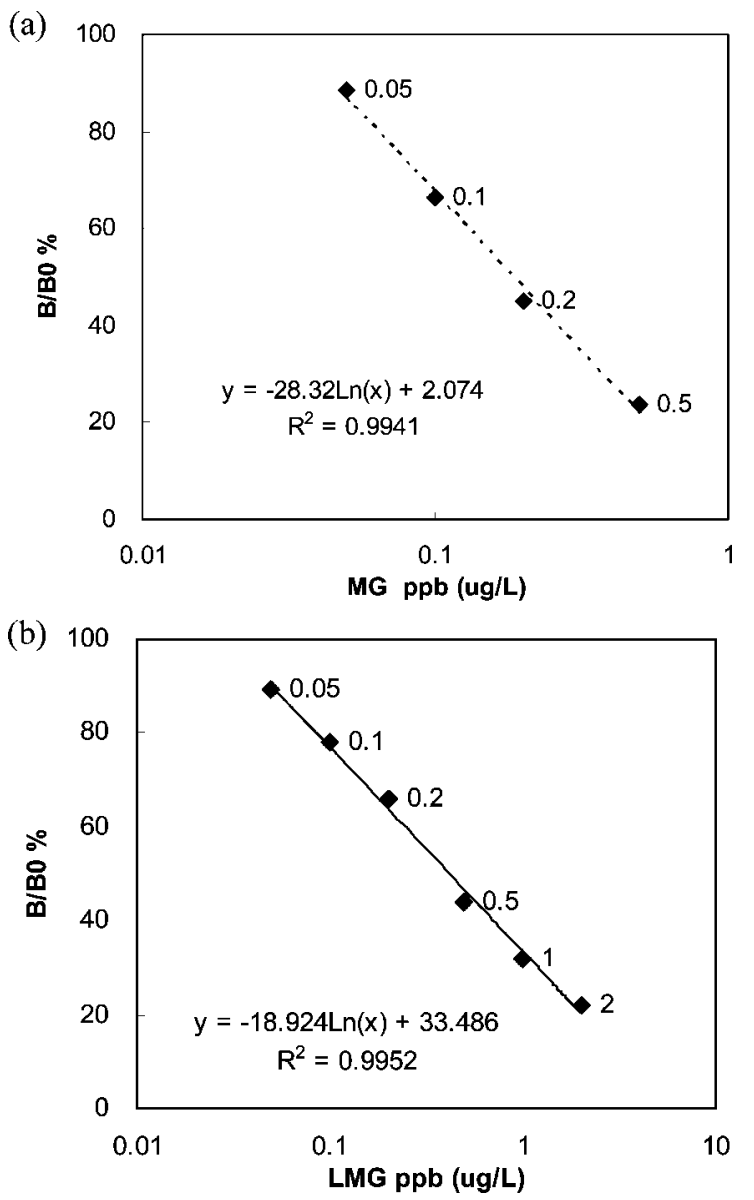

Figure 2. Standard titration curves of $M G(a)$ and $L M G(b)$ obtained by ELISA. B: Absorbance of MG or LMG standard. BO: Absorbance of blank solution.

acetic acid $(0.75 \mathrm{~mL})$ in $\mathrm{CHCl}_{3}(45 \mathrm{~mL})$ was stirred at $25^{\circ} \mathrm{C}$ for $1.5 \mathrm{~h}$. The solids were collected by filtration, rinsed with $\mathrm{CHCl}_{3} / \mathrm{CCl}_{4}(1: 1)$, and dried over $\mathrm{KOH}$ in vacuum to give crude CMG (360 mg), which was used without further purification for coupling with protein.

Method B. According to the previously described procedure (34), a mixture of CLMG $(150 \mathrm{mg}, 0.60 \mathrm{mmol})$ and $\mathrm{PbO}_{2}(0.63 \mathrm{mmol})$ in aqueous $\mathrm{HCl}\left(1.5 \mathrm{~mL}\right.$ of $2 \mathrm{M}$ solution) was stirred at $25^{\circ} \mathrm{C}$ for $18 \mathrm{~h}$. The mixture was diluted with $\mathrm{MeOH}(30 \mathrm{~mL})$ and filtered through a Celite bed. The filtrate was concentrated in vacuum to give green solids of CMG (246 mg), which were used without further purification for coupling with protein. By a similar procedure, CLMG methyl ester was treated with $\mathrm{PbO}_{2}$ in aqueous $\mathrm{HCl}$ to give $\mathrm{CMG}$ methyl ester. Complete oxidation of CLMG using both methods was indicated by disappearance of the methine signal at $\delta 5.42$ in the ${ }^{1} \mathrm{H}$ NMR spectrum of the CMG product. The structure of CMG was supported by an exact mass measurement, giving $\mathrm{m} / \mathrm{z} 373.1895$ for the parent ion $\left[\mathrm{C}_{24} \mathrm{H}_{25} \mathrm{~N}_{2} \mathrm{O}_{2}\right]^{+}$. The prepared CMG was estimated at $\sim 90 \%$ purity, and was good enough for the antibody production as shown in the inhibition assay without interference of any impurity (see Figure 3a). $C M G .{ }^{1} \mathrm{H}$ NMR $\left(\mathrm{CD}_{3} \mathrm{OD}, 400 \mathrm{MHz}\right) \delta 8.16(2 \mathrm{H}, \mathrm{d}, J=7.8$ $\mathrm{Hz}), 7.46(2 \mathrm{H}, \mathrm{d}, J=7.8 \mathrm{~Hz}), 7.41(2 \mathrm{H}, \mathrm{d}, J=8.0 \mathrm{~Hz}), 7.12$ 
(a)

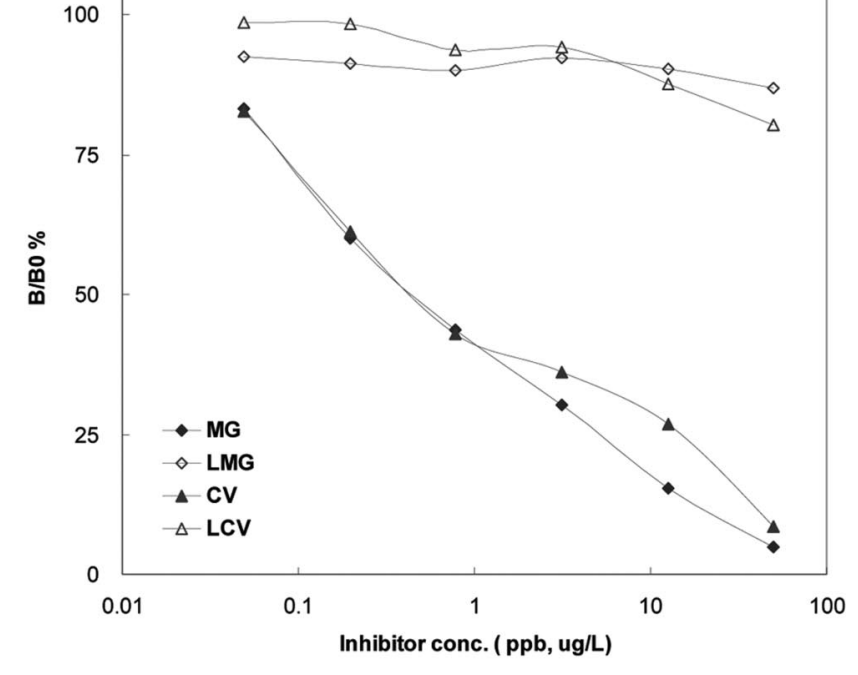

(b)

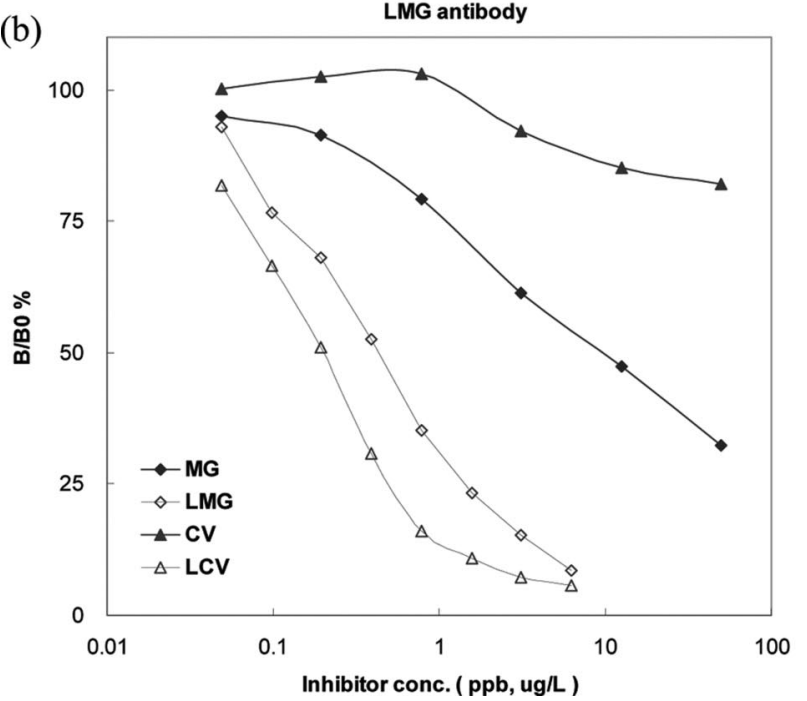

Figure 3. (a) Cross-reactivity of $M G$ antibody against $\mathrm{CV}$, and (b) crossreactivity of LMG antibody against MG and LCV.

$(2 \mathrm{H}, \mathrm{d}, J=8.0 \mathrm{~Hz}), 3.97(3 \mathrm{H}, \mathrm{s}), 3.34(12 \mathrm{H}, \mathrm{s})$. HRMS (ESI) calculated for $\mathrm{C}_{24} \mathrm{H}_{25} \mathrm{~N}_{2} \mathrm{O}_{2}: 373.1911$, found: $m / z 373.1895$ $\left[\mathrm{M}^{+}\right]$.CMG Methyl Ester. ${ }^{1} \mathrm{H}$ NMR $\left(\mathrm{CD}_{3} \mathrm{OD}, 400 \mathrm{MHz}\right) \delta 8.18$ $(2 \mathrm{H}, \mathrm{d}, J=7.8 \mathrm{~Hz}), 7.40-7.35(4 \mathrm{H}, \mathrm{m}), 7.05(2 \mathrm{H}, \mathrm{d}, J=8.4$ $\mathrm{Hz}), 3.35(12 \mathrm{H}, \mathrm{s})$. HRMS (ESI) calculated for $\mathrm{C}_{25} \mathrm{H}_{27} \mathrm{~N}_{2} \mathrm{O}_{2}$ : 387.2067, found: $m / z, 387.2197\left[\mathrm{M}^{+}\right]$.

Preparation of Immunogens by Coupling of CMG and CLMG with Proteins. In this study, OVA was used as a carrier for MG and LMG immunogens, and BSA was used as a carrier for the coated antigens in ELISA. To $0.85 \mathrm{~mL}$ of CMG or CLMG solution at $1 \mathrm{mg} /$ $\mathrm{mL}$ in $0.1 \mathrm{M}$ MES ( $\mathrm{pH} 6.0$ ) with $50 \% \mathrm{Me}_{2} \mathrm{SO}$ were added $\mathrm{N}$-(3dimethylaminopropyl)- $N^{\prime}$-ethylcarbodiimide (EDCI) hydrochloride (0.44 $\mathrm{mg}$ ) and $N$-hydroxysuccinimide (NHS, $0.26 \mathrm{mg}$, Pierce, USA). The mixture was stirred for $30 \mathrm{~min}$ at room temperature, and added dropwise to $5 \mathrm{~mL}$ of $1 \mathrm{mg} / \mathrm{mL}$ protein solution. The mixture was agitated for $2 \mathrm{~h}$ at room temperature. The conjugates were dialyzed against $0.1 \mathrm{M}$ phosphate buffer ( $\mathrm{pH}$ 7.4) to remove free reagents.

Immunization. Two groups of New Zealand rabbits (in duplicate) were immunized by sc injection with CMG-OVA or CLMG-OVA. Primary immunizations were composed of $500 \mu \mathrm{L}$ of PBS containing $100 \mu \mathrm{g}$ of immunogen emulsified in $500 \mu \mathrm{L}$ of Freund's complete adjuvant. Subsequent immunizations, at 2-5 week intervals, were of the same volume, with complete adjuvant replaced by incomplete adjuvant. Rabbits were bled after each injection. The sera titer was detected by an indirect ELISA.
Characterization of MG and LMG Antibodies. The 96-well plates (Corning, NY) were coated with MG-BSA or LMG-BSA overnight at $4{ }^{\circ} \mathrm{C}$. The plates were washed 3 times with PBST, and then blocked with $0.1 \%$ skim milk at $37{ }^{\circ} \mathrm{C}$ for $1 \mathrm{~h}$. The plates were again washed with PBST, and incubated with animal sera (100 $\mu \mathrm{L} /$ well) diluted in $0.1 \%$ BSA at $37^{\circ} \mathrm{C}$ for $1 \mathrm{~h}$. After incubation, plates were washed with PBST three times. Goat anti-rabbit IgG antibody conjugated with HRP was diluted (1/2000) in $0.1 \%$ BSA, and $100 \mu \mathrm{L}$ of the resultant solution was added to each well. The plates were incubated at $37^{\circ} \mathrm{C}$ for $1 \mathrm{~h}$, and washed again with PBST three times. The substrate solution TMB $\left(100 \mu \mathrm{L}\right.$ ) was added to each well and incubated at $37{ }^{\circ} \mathrm{C}$ for $10 \mathrm{~min}$. The reaction was stopped by addition of aqueous $\mathrm{HCl}(50 \mu \mathrm{L}$ of $2 \mathrm{M}$ solution). Optical density at a wavelength of $450 \mathrm{~nm}$ in each well was read using an ELISA reader.

The MG- and LMG-specific antibodies were purified from hightiter rabbit serum by affinity chromatography on a Protein A-Sepharose column (GE Healthcare, UK). The antibodies were concentrated using Centriprep (Amicon Ultra, 50000 MWCO; Millipore, USA). Antibody concentrations was measured with Bio-Rad protein assay (Bio-Rad Laboratories, Hercules, CA).

The specificity of MG and LMG antibodies was determined by indirect competitive ELISA using MG, LMG, CV, and leucocrystal violet (LCV) as inhibitors. The inhibitors were diluted in $0.02 \mathrm{M} \mathrm{HCl}$ with $0.15 \mathrm{M} \mathrm{NaCl}$. The indirect competitive ELISA was performed on MG-BSA or LMGBSA coated 96-well plates. Serially diluted inhibitors were incubated with $0.5 \mu \mathrm{g} / \mathrm{mL}$ of $\mathrm{MG}$ or $1.8 \mu \mathrm{g} / \mathrm{mL}$ of LMG antibodies in the antigen-coated 96-well plates at $37^{\circ} \mathrm{C}$ for $30 \mathrm{~min}$. Antibodies bound to the MG-BSA or LMG-BSA were detected by goat anti-rabbit IgG-HRP, followed by treatment with TMB. The optical density at a wavelength of $450 \mathrm{~nm}$ was recorded using an ELISA reader. The cross-reactivity of MG and LMG antibodies was expressed as the ratio of MG or LMG concentration to the cross-reactant concentration that will show $50 \%$ of B/B0 \%. For comparison, 13 common antibiotics/sulfonamides and 3 benzene derivatives were also tested by a similar procedure.

Preparation of Fish Samples for ELISA. Fish samples were obtained from the local market including Oreochomis sp. (Tilapia and Taiwan Tilapia), Chanos chanos (milkfish), Epinephelus sp. (grouper), Lateolabrax japonicus (Japanese sea perch), Micropterus salmoides (California bass), and Pagrus major (Red sea bream). The fish was filleted, the skin and bones were removed, and the muscles were minced and frozen before being analyzed. Accurately weighed $1.0 \mathrm{~g}$ of homogenized fish muscle was put into a $15 \mathrm{~mL}$ centrifuge tube, which can be spiked with appropriate amounts of MG or LMG, and $1 \mathrm{~mL}$ of McIlvaine buffer $(\mathrm{pH}=3.0)$ and $6 \mathrm{~mL}$ of acetonitrile were added. The mixture was vigorously vortexed for $3 \mathrm{~min}$, and centrifuged at $3500 \mathrm{rpm}$ for $10 \mathrm{~min}$. The supernatant was transferred into a centrifuge tube with $1.5 \mathrm{~mL}$ of $\mathrm{CH}_{2} \mathrm{Cl}_{2}$, and the sample was vortex-mixed followed by centrifuging at $3500 \mathrm{rpm}$ for $10 \mathrm{~min}$. An aliquot of the upper organic phase $(0.5 \mathrm{~mL})$ was transferred into a tube $(1.5 \mathrm{~mL})$, and treated with strong anion exchanger AG 1 resin $(0.1 \mathrm{~mL}$, Bio-Rad Laboratories, Hercules, CA) at room temperature for $30 \mathrm{~min}$ to reduce interference from the extracts. The supernatant $(0.4 \mathrm{~mL})$ was dried by evaporation under a stream of nitrogen at $50{ }^{\circ} \mathrm{C}$. The sample was reconstituted with $0.4 \mathrm{~mL}$ of sample diluent $(0.01 \mathrm{M} \mathrm{HCl})$ and detected by an $\mathrm{MG}$ or LMG ELISA.

MG ELISA of Fish Samples. MG-BSA was coated on a 96-well ELISA plate and reacted with fish samples and MG antibodies in equal volume at $37^{\circ} \mathrm{C}$ for $30 \mathrm{~min}$. Unbound MG antibodies were removed by washing. Goat anti-rabbit IgG-HRP was added and treated with TMB. The quantity of MG antibodies bound on the MG ELISA plate was deduced from the OD at $450 \mathrm{~nm}$. The percent binding (B/B0 \%) for each standard or sample was calculated by the following equation, and the corresponding concentration of MG was interpolated from the standard curve. The sample concentration was corrected for dilution (7-fold).

[OD (standard or sample)/OD (blank) $] \times 100 \%=\mathrm{B} / \mathrm{B} 0 \%$

LMG ELISA of Fish Samples. For LMG ELISA, an ELISA plate was coated with LMG-BSA. The fish samples and LMG antibodies in equal volume were subjected to indirect competitive ELISA, and the concentration of LMG was calculated by a procedure similar to that for MG ELISA. 
Scheme 1. Synthesis of Carboxymalachite Green (CMG) and Carboxyleucomalachite Green (CLMG)

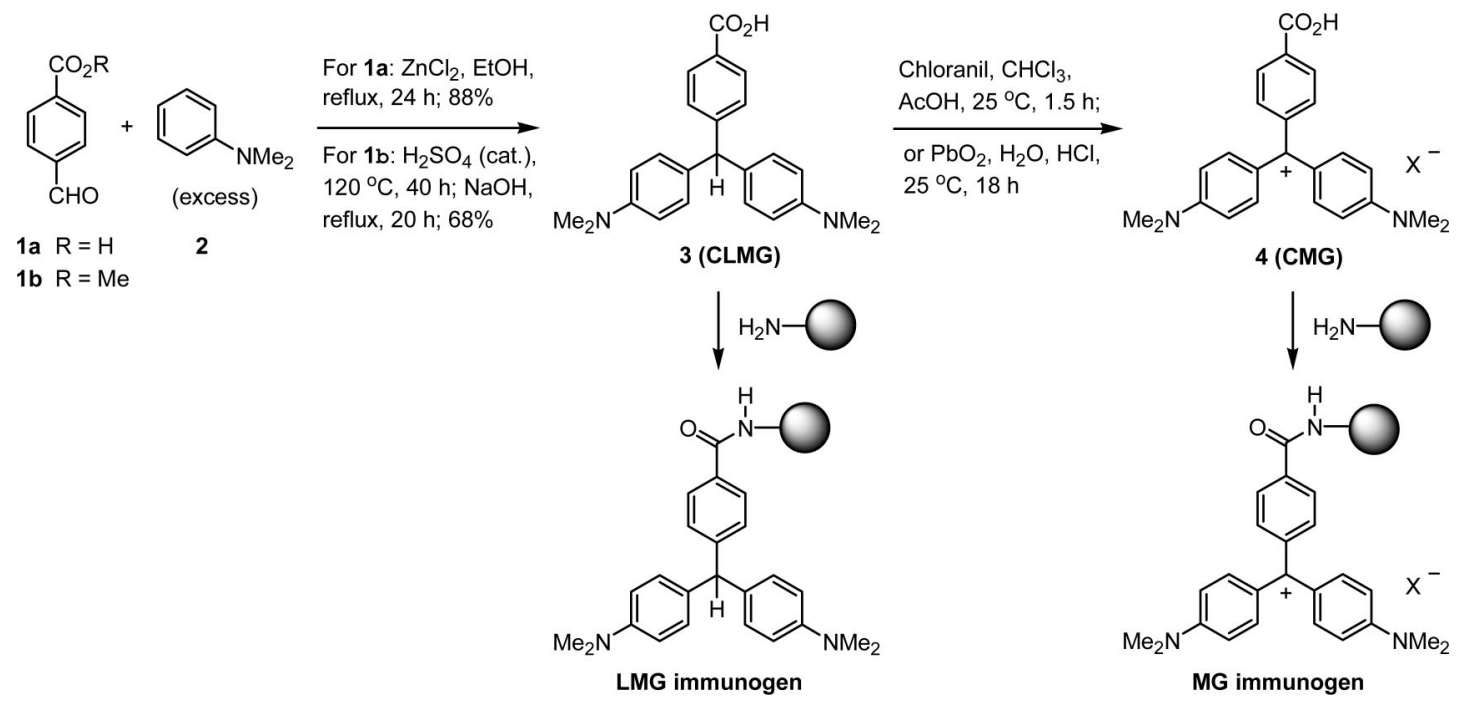

MG ELISA of Fishpond Water. The water sample collected from fishponds was diluted with 3 volumes of $0.02 \mathrm{M} \mathrm{HCl}$, with or without spiking of MG at 0.5 or $2 \mu \mathrm{g} / \mathrm{L}$. The sample was centrifuged at 3500 rpm for $10 \mathrm{~min}$, and an aliquot of supernatant $(100 \mu \mathrm{L})$ was taken for the MG ELISA.

\section{RESULTS AND DISCUSSION}

The compounds CLMG (3) and CMG (4) bearing a carboxyl group on the phenyl ring were designed as the appropriate analogues of MG and LMG for linkage with carrier proteins (Scheme 1). The synthesis of CLMG and CMG is straightforward by using known methods with minor modification (30-34).

LCMG and CMG were attached to the carrier proteins BSA and OVA via amide bond formation using NHS and EDCI as the condensation agents. Two groups of New Zealand rabbits (in duplicate) were immunized by subcutaneous injection with the MG- and LMG-OVA immunogens prepared as such to generate the specific antibodies, respectively, using the standard procedures. The results of the MG- and LMG-ELISA produced linear ranges from 0.05 to $0.5 \mu \mathrm{g} / \mathrm{L}$ of MG (Figure 2a) and from 0.05 to $2 \mu \mathrm{g} / \mathrm{L}$ of $\mathrm{LMG}$ (Figure $\mathbf{2 b}$ ). The detection limit of this assay was $0.05 \mu \mathrm{g} / \mathrm{L}$ for both MG and LMG, lower than the regulatory limit by the European Commission and U.S. Food \& Drug Administration (10).

Both our MG- and LMG-ELISA kits use a cutoff level of 1 $\mu \mathrm{g} / \mathrm{kg}$ to distinguish positive from negative samples. A total of 53 fish samples were detected by MG ELISA. The MG concentrations in fish muscle were spiked with 0.5 or $2 \mu \mathrm{g} / \mathrm{kg}$ of $\mathrm{MG}$, followed by 7-fold dilution, in appropriate cases for the ELISA experiments. There was $98 \%$ agreement between the results obtained by ELISA and theoretical concentration. The result shows $100 \%$ sensitivity and $96 \%$ specificity (Table 1). The recovery of MG-spiked samples was varied from $71 \%$ to $108 \%$. A total of 115 fish samples were detected by LMG ELISA. The LMG concentrations in fish muscle were spiked with $0.5,0.75,1.5$, or $2 \mu \mathrm{g} / \mathrm{kg}$ of LMG in appropriate cases for analysis. There was $90 \%$ agreement between the results obtained by ELISA and those by theoretical concentration. The result shows $83 \%$ sensitivity and $98 \%$ specificity (Table 1). The recovery of LMG-spiked samples was varied from $62 \%$ to $105 \%$. It was noted that fatty samples might cause lower recovery of LMG, and thus inferior sensitivity in ELISA. Presumably due to the lipophilic nature of LMG, the extraction from fatty samples might become less efficient.
Table 1. Comparison of MG and LMG Concentrations Determined by ELISA and Theoretical Concentrations in Fish Muscle $(n=53$ for MG and $n=115$ for LMG)

\begin{tabular}{lrrrrr}
\hline & \multicolumn{2}{c}{ MG } & & \multicolumn{2}{c}{ LMG } \\
\cline { 2 - 3 } \cline { 5 - 6 } ELISA & $+^{a}$ & $-{ }^{b}$ & & $+^{c}$ & $-{ }^{b}$ \\
\hline$+^{d}$ & 26 & 1 & 50 & 1 \\
$-^{e}$ & 0 & 26 & 10 & 54 \\
sensitivity $^{f}$ & $100 \%$ & & $83 \%$ & $98 \%$ \\
specificity $^{g}$ & & $96 \%$ & & 9
\end{tabular}

${ }^{a} \mathrm{MG}$ at concentration of 0.5 or $2 \mu \mathrm{g} / \mathrm{L}$ was spiked into the samples. ${ }^{b}$ No MG or LMG was spiked into the samples. ${ }^{c} \mathrm{LMG}$ at concentration of $0.5,0.75,1.5$, or $2 \mu \mathrm{g} / \mathrm{L}$ was spiked into the samples. ${ }^{d}$ Positive result of the relevant ELISA. ${ }^{e}$ Negative result of the relevant ELISA. ${ }^{f} \%$ sensitivity $=($ True positives - False negatives)/(True positives) $\times 100 \%{ }^{g} \%$ specificity $=($ True negatives - False positives)/(True negatives) $\times 100 \%$

Table 2. Comparison of MG Concentrations Determined by ELISA and Theoretical Concentrations in Water Samples $(n=27)$

\begin{tabular}{lrr}
\hline & \multicolumn{2}{c}{ MG } \\
\cline { 2 - 3 } ELISA & \multicolumn{1}{c}{+} \\
\hline+ & 9 & 0 \\
- & $100 \%$ & 18 \\
sensitivity & & $100 \%$ \\
specificity & &
\end{tabular}

MG ELISA was also used for fishpond water detection. The samples were diluted and directly analyzed by MG ELISA without the need of extraction or prior preparation. A total of 27 water samples were tested. The result showed that sensitivity and specificity are both $100 \%$ (Table 2 ).

The MG and LMG antibodies were insensitive to common antibiotics, sulfonamides, and benzene derivatives. No crossreactivity $(<0.005 \%)$ in the ELISA was observed in the 16 test compounds, including sulfadiazine, sulfamonomethoxine, sulfamethazine, sulfamethoxypyridazine, sulfadimethoxine, sulfathiazole, sulfaquinoxaline, Sulfamethoxazole, penicillin G, gentamicin, oxytetracycline, tetracycline, chloramphenicol, aniline, dimethylaniline and benzaldehyde, up to a concentration of 1000 $\mu \mathrm{g} / \mathrm{L}$.

The specificity of MG and LMG antibodies for the triphenylmethane dyes MG and CV as well as their metabolites LMG and LCV were investigated by indirect competitive ELISA. The MG antibody showed $100 \%$ cross-reactivity to CV, but was 
insensitive to LMG or LCV (Figure 33a). This result might be attributable to the similar structures between MG and CV having 4-(dimethylamino)phenyl groups surround the methylium center of planar shape (Figure 11). Because LCV exhibited a methine center of tetrahedral shape, as that of LMG, the LMG antibody also reacted strongly with LCV (200\% cross-reactivity), but not with CV (Figure 3b). A slight cross-reactivity of the LMG antibody with MG $(\sim 3 \%)$ was also observed. The reason is unclear, though we speculate that a small amount of MG may be derived from air oxidation of LMG during the process of immunogen preparation and immunization.

To our knowledge, using the commercially available ELISA kits, e.g., MaxSignal Malachite Green ELISA Test Kit of Bioo Scientific Co. (Texas, USA), for detection of LMG in fish samples requires a prior oxidation of LMG to MG. On the other hand, our LMG ELISA is directly applied to detection of LMG in fish samples. Though a side-by-side comparison experiment was not carried out, our MG ELISA shows a detection limit of $0.05 \mu \mathrm{g} / \mathrm{L}$, better than the BIOO specification $(0.5 \mu \mathrm{g} / \mathrm{L})$.

In conclusion, we have successfully utilized CMG-OVA and CLMG-OVA as immunogens to produce, respectively, a high titer of rabbit polyclonal antibodies against MG and LMG. Detection of MG and LMG residues in spiked fish muscle with the ELISA kits showed $96 \%$ specificity and $100 \%$ sensitivity for the MG antibody, as well as $98 \%$ specificity and $83 \%$ sensitivity for the LMG antibody. The diluted fishpond water, without extraction or prior preparation, was directly subjected to the MG ELISA analysis to show $100 \%$ specificity and 100 $\%$ sensitivity. MG and LMG were readily detected in a concentration as low as $0.05 \mu \mathrm{g} / \mathrm{L}$ by our ELISA kits in a short period of time $(<2 \mathrm{~h})$, including the time needed for fish sample preparation. The described ELISA method allows a direct analysis of MG and LMG in fish and water samples without an additional step for oxidation of LMG to MG, which is often required in the previously reported methods using HPLC and LC-MS. While HPLC methods are used for quantitative and confirmatory determination of MG and LMG in aquaculture products, the ELISA method is good for rapid on-site screening in a semiquantitative sense.

\section{ABBREVIATIONS USED}

BSA, bovine serum albumin; CLMG, carboxyleucomalachite green; $\mathrm{CMG}$, carboxymalachite green; $\mathrm{CV}$, crystal violet; $\mathrm{DEPT}$, distortionless enhancement by polarization transfer; EDCI, $N$-(3dimethylaminopropyl)- $N^{\prime}$-ethylcarbodiimide; ELISA, enzymelinked immunosorbent assay; ESI, electrospray ionization; FTNMR spectrometer, Fourier transform nuclear magnetic resonance spectrometer; HPLC, high performance liquid chromatography; HRMS, high-resolution mass spectra; HRP, horseradish peroxidase; IgG, immunoglobulin G; IR spectra, infrared spectra; LC-MS, liquid chromatography-mass spectrometry; LCV, leucocrystal violet; LMG, leucomalachite green; MG, malachite green; MES, 2-( $N$-morpholino)ethanesulfonic acid; MS, mass spectrometry or mass spectra; NHS, $N$-hydroxysuccinimide; NMR spectra, nuclear magnetic resonance spectra; OD, optical density; OVA, ovalbumin; PBS, phosphate-buffered saline; PBST, phosphate-buffered saline with $0.05 \%$ Tween 20; TMB, 3,3',5,5'-tetramethylbenzidine; TLC, thin-layer chromatography; TMS, tetramethylsilane.

\section{LITERATURE CITED}

(1) Alderman, D. J. Malachite green: a review. J. Fish Dis. 1985, 8, 289-298.
(2) Plakas, S. M.; El Said, K. R.; Stehly, G. R.; Gingerich, W. H.; Allen, J. H. Uptake, tissue distribution, and metabolism of malachite green in the channel catfish (Ictalurus punctatus). Can. J. Fish Aquat. Sci. 1996, 53, 1427-1433.

(3) Plakas, S. M.; Doerge, D. R.; Turnipseed, S. B. Disposition and metabolism of malachite green and other therapeutic dyes in fish. In Xenobiotics in Fish; Beconi-Barker, M., Gingerich, W. H., Smith, D. J., Eds.; Plenum Press: New York, 1999; pp 149-166.

(4) Culp, S. J.; Beland, F. A. Malachite green: A toxicological review. J. Am. Coll. Toxicol. 1996, 15, 219-238.

(5) Fernandes, C.; Lalitha, V. S.; Rao, K. V. K. Enhancing effect of malachite green on the development of hepatic pre-neoplastic lesions induced by $\mathrm{N}$-nitrosodiethylamine in rats. Carcinogenesis 1991, 12, 839-845.

(6) Culp, S. J.; Blankenship, L. R.; Kusewitt, D. F.; Doerge, D. R.; Mulligan, L. T.; Beland, F. A. Toxicity and metabolism of malachite green and leucomalachite green during short-term feeding to Fischer 344 rats and B6C3F1 mice. Chem. Biol. Interact. 1999, 122, 153-170.

(7) Mittelstaedt, R. A.; Mei, N.; Webb, P. J.; Shaddock, J. G.; Dobrovolsky, V. N.; McGarrity, L. J.; Morris, S. M.; Chen, T.; Beland, F. A.; Greenlees, K. J.; Heflich, R. H. Genotoxicity of malachite green and leucomalachite green in female Big Blue B6C3F1 mice. Mutat. Res. 2004, 561, 127-138.

(8) Schnick, R. A. An overview of current programs on drug development and regulation for aquaculture: US Fish and Wildlife Service perspective. Vet. Hum. Toxicol. 1991, 33 (Suppl. 1), 45.

(9) Veterinary Residues Committee. Annual Report on Surveillance for Veterinary Residues in Food in the UK for 2001, 2002, and 2003, available at http://www.vet-residues-committee.gov.uk/.

(10) Commission Decision 2004/25/EC as regards the setting of minimum required performance limits (MRPLs) for certain residues in food of animal origin. Official Journal of the European Union 2004, L6, 38-39.

(11) Allen, J. L.; Gofus, J. E.; Meinertz, J. R. Determination of malachite green residues in the eggs, fry, and adult muscle tissue of rainbow trout (Oncorhynchus mykiss). J. AOAC Int. 1994, 77, $553-557$.

(12) Roybal, J. E.; Pfenning, A. P.; Munns, R. K.; Holland, D. C.; Hurlbut, J. A.; Long, A. R. Determination of malachite green and its metabolite, leucomalachite green, in catfish (Ictalurus punctatus) tissue by liquid chromatography with visible detection. J. AOAC Int. 1995, 78, 453-457.

(13) Turnipseed, S. B.; Roybal, J. E.; Hurlbut, J. A.; Long, A. R. Gas chromatographic/mass spectrometric confirmation of leucomalachite green in catfish (Ictalurus punctatus) tissue. J. AOAC Int. 1995, 78, 971-977.

(14) Plakas, S. M.; el Said, K. R.; Stehly, G. R.; Roybal, J. E. Optimization of a liquid chromatographic method for determination of malachite green and its metabolites in fish tissues. J. AOAC Int. 1995, 78, 1388-1394.

(15) Doerge, D. R.; Churchwell, M. I.; Gehring, T. A.; Pu, Y. M.; Plakas, S. M. Analysis of malachite green and matabolites in fish using liquid chromatography atmospheric pressure chemical ionization mass spectrometry. Rapid Commun. Mass Spectrom. 1998, 12, 1625-1634.

(16) Tarbin, J. A.; Barnes, K. A.; Bygrave, J.; Farrington, W. H. H. Screening and confirmation of triphenylmethane dyes and their leuco metabolites in trout muscle using HPLC-vis and ESPLCMS. Analyst 1998, 123, 2567-2571.

(17) Bergwerff, A. A.; Scherpenisse, P. Determination of residues of malachite green in aquatic animals. J. Chromatogr., B 2003, 788, 351-359.

(18) U.S. Food and Drug Administration. Guideline for Industry: Mass spectrometry for confirmation of the identity of animal drug residues. Fed. Regist. 2003, 68, 25617-25618.

(19) Brandt, A.-M.; Laerke, S. Determination of malachite green and leucomalachite green by HPLC with postcolumn oxidation. In Proceedings of the EuroResidue V Conference;Noordwijkerhout, The Netherlands, 2004; pp 358-362. 
(20) Van Rhijn, J. A.; Mulder, P. P. J.; van Baardewijk, F.; te Brinke, E. M.; Lasaroms, J. J. P. Confirmatory analysis of traces of malachite green and its main metabolite leucomalachite green in muscle tissue of Atlantic salmon. In Proceedings of the EuroResidue $V$ Conference; Noordwijkerhout, The Netherlands, 2004; pp 808-813.

(21) Turnipseed, S. B.; Andersen, W. C.; Roybal, J. E. Determination and confirmation of leucomalachite green in salmon using nodischarge atmospheric pressure chemical ionization LC-MS. US Food Drug Admin. Lab. Inf. Bull. 2004, 20, LIB No. 4333.

(22) Valle, L.; Diaz, C.; Zanocco, A. L.; Richter, P. Determination of the sum of malachite green and leucomalachite green in salmon muscle by liquid chromatography-atmospheric pressure chemical ionisation-mass spectrometry. J. Chromatogr., A 2005, 1067, 101105.

(23) Scherpenisse, P.; Bergwerff, A. A. Determination of residues of malachite green in finfish by liquid chromatography tandem mass spectrometry. Anal. Chim. Acta 2005, 529, 173-177.

(24) Mitrowska, K.; Posyniak, A.; Zmudzki, J. Determination of malachite green and leucomalachite green in carp muscle by liquid chromatography with visible and fluorescence detection. J. Chromat. A 2005, 1089, 187-192.

(25) Van de Riet, J. M.; Murphy, C. J.; Pearce, J. N.; Potter, R. A.; Burns, B. G. Determination of malachite green and leucomalachite green in a variety of aquacultured products by liquid chromatography with tandem mass spectrometry detection. J. AOAC Int. 2005, 88, 744-749.

(26) Andersen, W. C.; Roybal, J. E.; Turnipseed, S. B. Liquid chromatographic determination of malachite green and leucomalachite green (LMG) residues in salmon with in situ LMG oxidation. J. AOAC Int. 2005, 88, 1292-1298.

(27) Turnipseed, S. B.; Andersen, W. C.; Roybal, J. E. Determination and confirmation of malachite green and leucomalachite green residues in salmon using liquid chromatography with no-discharge atmospheric pressure chemical ionization. J. AOAC Int. 2005, 88 , 1312-1317.

(28) Turnipseed, S. B.; Andersen, W. C.; Karbiwnyk, C. M.; Roybal, J. E.; Miller, K. E. No-discharge atmospheric pressure chemical ionization: Evaluation and application to the analysis of animal drug residues in complex matrices. Rapid Commun. Mass Spectrom. 2006, 20, 1231-1239.

(29) Andersen, W. C.; Turnipseed, S. B.; Roybal, J. E. Quantitative and confirmatory analyses of malachite green and leucomalachite green residues in fish and shrimp. J. Agric. Food Chem. 2006, $54,4517-4523$.

(30) Müller, W.; Hattesohl, I.; Schuetz, H. J.; Meyer, G. Polyethylene glycol derivatives of base and sequence specific DNA ligands: DNA interaction and application for base specific separation of DNA fragments by gel electrophoresis. Nucleic Acids Res. 1981, 9, 95-119.

(31) Inoue, T.; Kikuchi, K.; Hirose, K.; Iino, M.; Nagano, T. Small molecule-based laser inactivation of inositol 1,4,5-trisphosphate receptor. Chem. Biol. 2001, 8, 9-15.

(32) Finer, J. T.; Chabala, J. C.; Lewis, E. Preparation of triphenylmethanes as kinesin KSP inhibitors. PCT Int. Appl. 2002, 50.

(33) Nakanishi, W.; Kikuchi, K.; Inoue, T.; Hirose, K.; Iino, M.; Nagano, T. Hydrophobic modifications at 1-phosphate of inositol 1,4,5-Trisphosphate analogues enhance receptor binding. Bioorg. Med. Chem. Lett. 2002, 12, 911-913.

(34) Cho, B. P.; Yang, T.; Blankenship, L. R.; Moody, J. D.; Churchwell, M.; Beland, F. A.; Culp, S. J. Synthesis and characterization of $\mathrm{N}$-demethylated metabolites of malachite green and leucomalachite green. Chem. Res. Toxicol. 2003, 16, 285294.

Received for review April 23, 2007. Revised manuscript received July 27, 2007. Accepted July 30, 2007. We thank the Council of Agriculture, Taiwan, for financial support [95-Rescure and Regulate-Fishery-01(2)].

JF071195Y 